\title{
The anti-osteoporotic effect of Moringa oleifera leaves extract on glucocorticoids-induced jawbone osteoporosis in Albino rats
}

\author{
Efeito anti-osteoporótico dos extratos de folhas de Moringa oleifera em osteoporose maxilar induzida por glicocorticóides \\ em ratos albinos

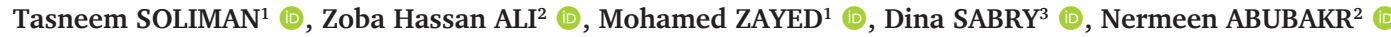 \\ 1 - Misr International University, Oral Biology department, Faculty of Dentistry, Cairo, Egypt. \\ 2 - Cairo University, Oral Biology Department, Faculty of Dentistry, Cairo, Egypt. \\ 3 - Cairo University, Faculty of Medicine, Medical Biochemistry and Molecular Biology Department, Cairo, Egypt.
}

\begin{abstract}
Objective: Glucocorticoids induced osteoporosis and its related fragility fractures represent a costly human and socioeconomic load worldwide. All the current pharmacological therapies possess multiple adverse effects and high cost. Thus, the pesent study aimed to evaluate the bone healing ability of Moringa oleifera (MO) on glucocorticoids induced osteoporosis in the jawbone of Albino rats. Material and Methods: Osteoporosis was prompted by a daily intraperitoneal injection of $200 \mu \mathrm{g} / 100 \mathrm{~g}$ dexamethasone for 30 days. Next,the animals were randomly divided into 2 groups; osteoporotic and MO treated group. The treated group receivd a daily oral dose of $200 \mathrm{mg} / \mathrm{kg}$ of MO. Rats from the MO group were sacrificed after 4 weeks from the beginning of treatment, and the same sacrifice date was used for the osteoporotic group. Bone regeneration was evaluated by dual energy x-ray absorptiometry (DEXA), real time polymerase chain reaction (RT-PCR), histopathological and histomorphometric examination. Results: After the sacrifice, the DEXA analysis revealed a significant upregulation in the BMD in the MO treated group ( $\mathrm{p}<0.001)$. The RT-PCR test showed a significant decline in RANKL gene expression and a significant rise in OPG gene expression in the MO group ( $<<0.001, p=0.002$, respectively). The histopathological examination of the MO group displayed a marked healing of the jawbone micro-anatomy. The histomorphometric analysis also showed that the bone area percentage increased significantly in the MO group ( $\mathrm{p}<0.05$ ). Conclusion: A cheap, easy to get, yet a powerful plant like MO leaves, can be cosidered an effective treatment for osteoporosis.
\end{abstract}

\section{KEYWORDS}

Bone regeneration; Glucocorticoids; Moringa oleifera; Osteoporosis.

\section{RESUMO}

Objetivos: A osteoporose induzida por glicocorticóides e suas fraturas por fragilidade relacionadas representam um custo humano caro e carga socioeconômica em todo o mundo. Todas as terapias farmacológicas atuais possuem múltiplos efeitos adversos e alto custo. Assim, o presente estudo teve como objetivo avaliar a capacidade de cicatrização óssea de Moringa oleifera (MO) em osteoporose induzida na mandíbula de ratos albinos. Material e Métodos: A osteoporose foi induzida por uma injeção intraperitoneal diária de $200 \mu \mathrm{g} / 100 \mathrm{~g}$ de dexametasona por 30 dias. A seguir, os animais foram divididos aleatoriamente em 2 grupos; grupo tratado com osteoporose e MO. O grupo tratado recebeu uma diária dose oral de $200 \mathrm{mg} / \mathrm{kg}$ de $\mathrm{MO}$. Os ratos do grupo MO foram eutanasiados após 4 semanas do início do tratamento, e a mesma data de eutanásia foi usada para o grupo osteoporótico. A regeneração óssea foi avaliada por espectrometria de raio-x de energia dupla (DEXA), reação em cadeia da polimerase em tempo real (RT-PCR), análise histopatológica e histomorfométrica. Resultados: Após a eutanásia, a análise DEXA revelou uma regulação positiva significativa na DMO no grupo tratado com MO ( $\mathrm{p}<0,001)$. O teste RT-PCR mostrou um declínio significativo na expressão do gene RANKL 
e um aumento significativo na expressão do gene OPG no grupo MO ( $p<0,001, p=0,002$, respectivamente). O exame histopatológico do grupo MO revelou uma cicatrização acentuada da microanatomia do maxilar. A análise histomorfométrica também mostrou aumento significativo na porcentagem de área óssea no grupo MO (p $<0,05)$. Conclusão: A MO é uma planta barata, de fácil obtenção, e suas folhas ainda podem ser consideradas poderosas como tratamento eficaz para a osteoporose.

\section{PALAVRAS-CHAVE}

Regeneração óssea; Glicocorticoides; Moringa olefeira; Osteoporose.

\section{INTRODUCTION}

Osteoporosis is a widespread systemic skeletal disease with the key feature of disturbed bone microarchitecture, resulting in high risk of bony fractures. Osteoporosis affects 1 in 4 women and more than 1 in 8 men over 50 years [1,2]. It was stated that the osteoporotic skeletal mass deterioration can be accompanied with an elevated oral bone loss. This subsequent low jaw bone density leads to increased alveolar bone porosity and changed trabecular pattern leading to faster alveolar bone resorption. Consequentially, the host system is progressively susceptible to infectious destruction of the periodontal tissues $[3,4]$.

Glucocorticoids (GCs) are the main iatrogenic cause for secondary osteoporosis, where the fracture risk increases by as much as $75 \%$ within the first 3 months of therapy [5]. GCs led to the increased production of macrophage colony stimulating factor (M-CSF) and receptor activator of nuclear factor kappa-beta (NF-kB) ligand RANKL and the decreased production of osteoprotegerin (OPG) by osteoblastic cells and osteocytes, subsequently increasing the number and activity of osteoclasts, that is why they have direct effects on bone resorption [6].

The long term use of pharmacological drugs in treatment of osteoporosis was proved to have several disadvantages. Bisphosphonates adverse effects range from upper gastrointestinal symptoms and musculoskeletal pain to atypical femur fractures and osteonecrosis of the jaw. Skin and urinary infections are seen with denosumab drug. An increased risk of strokes was noted with raloxifene which is a selective estrogen receptor modulator [7]. That's why shifting to a more natural bone healing approach was mandatory, especially with the presence of a powerful botanical extract like the Moringa oleifera.
Moringa oleifera Lam (MO) is a local medicinal Indian herb, mostly found in the subtropical and tropical regions. It comprises numerous nutrients such as calcium, vitamin D, magnesium and phosphorus that are correlated to a rise in bone density and have a serious role in calcium absorption and bone health. MO leaves are its most nutritious part. They act as a major source for B-vitamins, vitamin-C, pro-vitamin $\mathrm{A}$ as beta carotene, manganese, vitamin $\mathrm{K}$ and proteins [8-10].

Moringa leaf extract has an osteoblastic potential and indirect osteo-inductive properties because of its natural contents, being rich in flavonoids, saponins, tannins and phytoestrogens $[11,12]$. These flavonoids induce bone mineralization and bone nodule formation. In addition, they contain kaempferol and quercetin. Kaempferol was found to hinder the osteoclastic resorption and induce the osteoblastic differentiation and cells mineralization $[13,14]$.

Moreover, it was reported that the ethanolic extract of MO phytoestrogens content may have a protective action against ovarian hormone insufficiency related bone resorption. These phytoestrogens are similar to endogenous estrogens, estradiol. Therefore, they are considered as natural selective estrogen receptor modulators, as steroidal estrogens which have a positive stimulatory effect on osteoblast activity and a protective role in postmenopausal women [15].

In this context, this study aimed to assess the bone healing regenerative potential of MO leaf extract in treatment of osteoporosis through its oral intake.

\section{MATERIAL AND METHODS}

\section{Ethical statement}

This study was performed at the animal house, Faculty of Medicine, Cairo University after 
the acceptance of the Institutional Animal Care and Use Committee (IACUC), Cairo University (CU-III-F-73-17).

\section{Moringa oleifera (MO) ethanolic extract preparation}

MO leaves were collected from the farm of Egyptian Scientific Society of Moringa. The collected leaves were air-dried, powdered and kept for extraction. $200 \mathrm{~g}$ of the dry powdered MO leaves were extracted with $1 \mathrm{~L}$ of $70 \%$ ethanol and shaken every $8 \mathrm{~h}$ for $24 \mathrm{~h}$. After that, the hydroalcoholic extract was filtered using a cotton funnel. This step was repeated four times. The extract was concentrated using a rotator evaporator under reduced pressure. The concentrated extract was lyophilized and kept at $-20^{\circ} \mathrm{C}[16]$.

\section{Animals}

Eight Albino rats weighing 150-200 gm were used in the expeirment. They were placed in separate cages and kept under good ventilation. Rats were allowed to have free access to water and food ad-libitum. Rats were randomly divided into 2 groups of 4 rats each, as follows:

Osteoporotic group: included 4 glucocorticoidinduced osteoporotic rats. Rats received distilled water as a physiological solution via oral gavage to experience the same daily stress.

MO group: included 4 glucocorticoid-induced osteoporotic rats. Osteoporotic rats were given their regular rat chow and a daily dose of 200mg/ $\mathrm{kg}$ of Moringa oleifera extract via oral gavage [17].

\section{Study design}

The rats were subjected to an intraperitoneal injection of $200 \mu \mathrm{g} / 100 \mathrm{~g}$ dexamethasone once a day for 30 days for osteoporosis induction [18]. Jawbone BMD was measured to confirm that osteoporosis was effectively induced. Rats from the MO group were sacrificed after 4 weeks from beginning of treatment, with the exact sacrifice date for the osteoporotic untreated group. The lower jaw dissection and processing was done for the following:

\section{Dual-Energy X-ray Absorptiometry (DEXA) Analysis}

The Mandibular jaws BMD was evaluated using DEXA. Norland XR-46 DXA scanner (Norland Corp. Fort Atkinson, WI, USA) supplied with suitable software for bone evaluation was used. The scannig resolution was $0.5 \times 0.5 \mathrm{~mm}$ and the speed was $60 \mathrm{~mm} / \mathrm{sec}$. Examination was performed on the picture of the rat's jaw bone on the screen utilizing a region of interest (ROI) at the alveolar bone supporting the socket of the mandibular first molar. Results were shown automatically in $\mathrm{gm} / \mathrm{cm}^{2}$ [19].

\section{Real time PCR}

The RT-PCR determined the total RNA containing genes. RNAs were isolated by QIAZOL (QIAGEN). The cDNA was formed by the cDNA synthesis kit (Applied bio system) and RT-PCR was done by RTPCR kit (Applied bio system) on Step One Plus instrument (Applied Biosystems) using standardized protocols. The RQ of each target gene was measured by calculating the $\Delta \Delta \mathrm{Ct}$. The calculation of the RQ for the genes of interest was performed by $2-\Delta \Delta \mathrm{Ct}$ normalization to the housekeeping gene $G A D P H$. Primers for $R A N K L, O P G$ and GADPH are listed in Table I.

\section{Histopathological Examination}

The samples used were decalcified for 4-5 weeks, then dehydrated in ascending grades of alcohol, cleared in Xylol and inserted in paraffin blocks. Serial sections of 5-6 $\mu \mathrm{m}$ thickness were cut, placed on glass slides and stained with Hematoxylin and Eosin (H\&E) for routine histopathological examination.

Table I Primers' sequence specific for each gene

\begin{tabular}{cc} 
Gene symbol & Primer sequence from 5'- 3' \\
\hline RANKL & F: ACC AGC ATC AAA ATC CCA AG \\
OPG & R: TTT GAA AGC CCC AAA GTA CG \\
& F: GTT CTT GCA CAG CTT CAC CA \\
GAPDH & R: AAA CAG CCC AGT GAC CAT TC \\
& F: GACGGCCGCATCTTCTTGA \\
\hline
\end{tabular}




\section{Histomorphometric Analysis}

The bone area percentage in the area underneath the first molar for each sample was evaluated. Data was obtained using Leica Qwin 500 image analyzer computer system (England). The area and area percentage of bone trabeculae were calculated by an objective lens of magnification 20x (total magnification of 200). Five fields were calculated for each sample. The bone area percentage was calculated in relation to a standardized measuring frame possessing an area of $118476.6 \mu \mathrm{m} 2$.

\section{Statistical methods}

Data analysis was done with SPSS v24 software for Windows (SPSS Inc., Chicago, IL, USA). Results were expressed as mean \pm standard deviation for all variables. Pairwise comparisons between groups were performed using Student T-test. P-values less than 0.05 were considered statistically significant.

\section{RESULTS}

\section{DEXA results}

There was a significant upregulation in the BMD in the MO treated group compared to the osteoporotic group $(\mathrm{p}<0.001)$ (Table II).

\section{RT-PCR results}

A significant decline in RANKL gene expression in the MO treated group was found compared to the osteoporotic group ( $\mathrm{p}<0.001)$, while there was a significant upregulation in the OPG gene expression in the MO treated group compared to the osteoporotic group ( $\mathrm{p}$ value $=$ 0.002) (Table II).

\section{RANKL/OPG ratio among different studied groups}

There was a significant decline in RANKL/ OPG ratio in the MO treated group compared to the osteoporotic group ( $\mathrm{p}$ value $<0.001$ ) (Table II)

\section{Histopathological results}

The histopathological examination of the alveolar bone structure of the osteoporotic group displayed clear signs of degeneration. The bone marrow cavities grew wide and became filled with multiple chronic inflammatory cells and extravasated RBCs. The bone trabeculae became very thin, mal-organized and surrounded by multiple marrow spaces. In addition, areas of fatty degeneration filled with adipose tissue were observed in one of the marrow cavities. Some empty lacunae, multiple osteoporotic bony clefts and many areas in the marrow spaces with a diminished osteoblastic lining were also detected. All these findings denoted cellular degeneration (Figure 1).

The histopathological examination of the alveolar bone structure of the MO treated group showed a great evidence of bone healing. The marrow cavities got narrower and regained their osteoblastic lining. They became surrounded by more organized lamellar bone architecture. A fewer number of bony clefts was detected. The osteocytes were back to their normal size and shape, filling their lacunae throughout the bone trabeculae. The marrow cavities also showed increased cellularity where megakaryocytes and multiple granulocytes were observed. Bone resting lines, multinucleated osteoclasts and reversal scalloped lines with areas of newly formed bone matrix (osteoid) were also noted and denoted the active progressing bone remodeling and healing

Table II - DEXA, RT-PCR and histomorphometric results

\begin{tabular}{cccc} 
Test & Osteoporotic group & Moringa oleifera group & $P$ value \\
\hline DEXA level & $0.03 \pm 0.01$ & $0.1 \pm 0.02^{*}$ & $0.75 \pm 0.21^{*}$ \\
\hline RANKL gene expression & $2.6 \pm 0.19$ & $1.16 \pm 0.45^{\star}$ & $P<0.001$ \\
\hline OPG gene expression & $0.38 \pm 0.08$ & $0.78 \pm 0.45^{*}$ & $P=0.002$ \\
\hline RANKL/OPG ratio & $6.98 \pm 1.25$ & $64.44 \pm 4.9^{*}$ & $P<0.001$
\end{tabular}

Data are expressed as mean $\pm S D$; *Denotes statistical significance at $p$ value $<0.05$ 

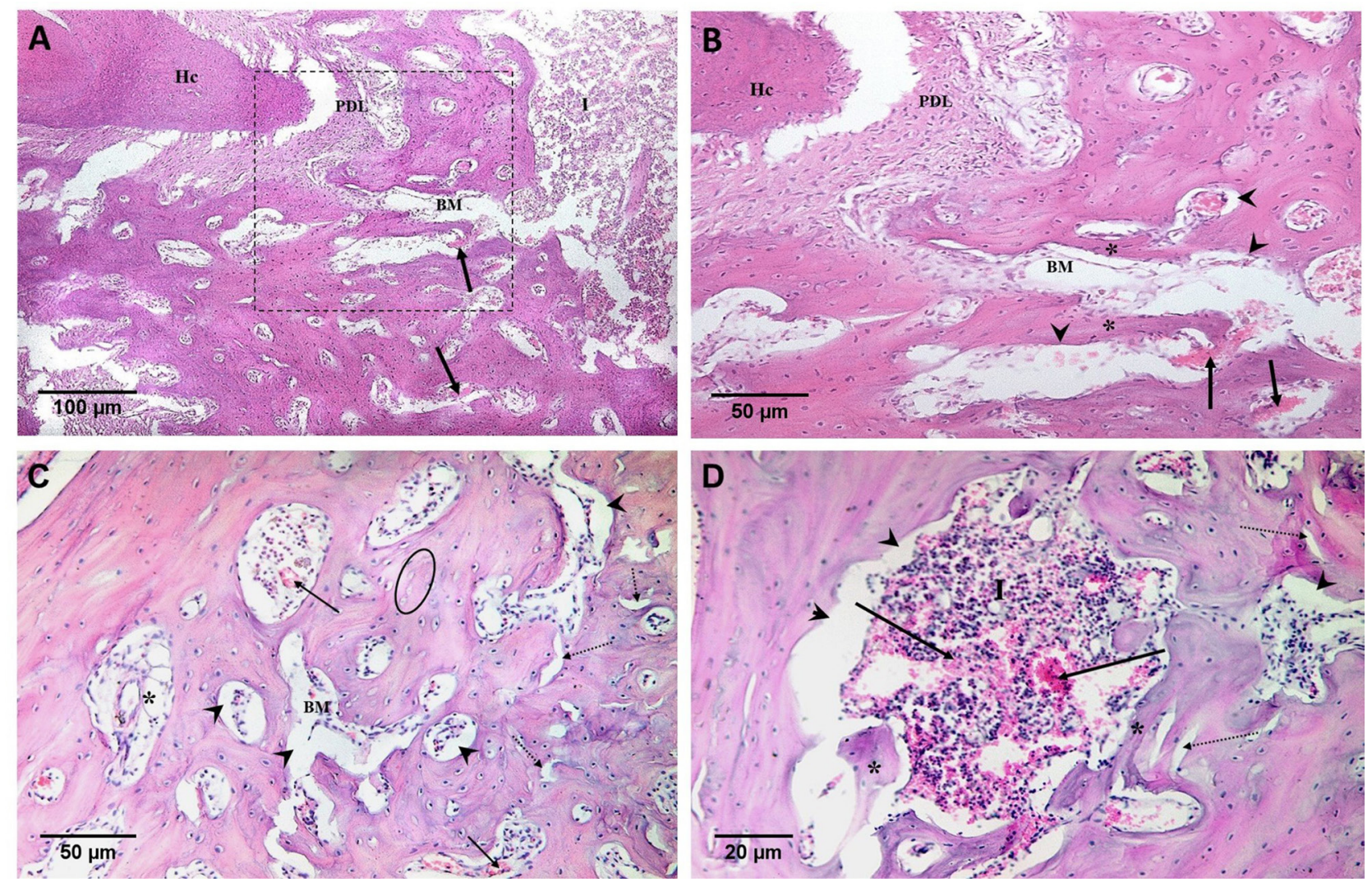

Figure 1 - A photomicrograph of the osteoporotic group showing (A) multiple widened bone marrow cavities (BM), a large marrow cavity filled with chronic inflammatory cells (I), hypercementosis (Hc) and degenerated periodontal ligaments (PDL) (H\&E, original Mag. X100, scale bar=100 $\mu \mathrm{m})$; (B) a higher magnification of the previous figure, showing wide bone marrow cavities (BM) with areas of extravasated RBCs (arrows), areas with diminished osteoblastic lining (arrow heads), areas of thin bone trabeculae (asterisks), hypercementosis (Hc) and degenerated periodontal ligaments (PDL) (H\&E, original Mag. X200, scale bar=50 $\mu \mathrm{m})$; (C) widened bone marrow cavities (BM), some with a reduced osteoblastic lining (arrow heads), areas of extravasated RBCs (arrows), empty lacunae (oval), multiple bony clefts (dotted arrows) and fatty degeneration (asterisk) (H\&E, original Mag. X200, scale bar $=50 \mu \mathrm{m}$ ); (D) a very wide marrow space containing multiple extravasated RBCs (arrows), chronic inflammatory cells (I) with a contracted osteoblastic lining (arrow heads) surrounded by thin bone lamellae (asterisks) and some bony clefts (dotted arrows) (H\&E, original Mag. X400, scale bar=20 $\mu \mathrm{m}$ ).

process. A network of vascular channels was observed. Also, a vascular canal turned into a secondary osteon, where the vascular canal was surrounded by centrally deposited lamellar bone with a reversal line (Figure 2).

\section{Histomorphometric results}

Comparing between MO treated group and the osteoporotic group, revealed that the bone area percentage values were statistically significantly different $(\mathrm{p}<0.05)$ (Table II).

\section{DISCUSSION}

Synthetic GCs are commonly used in treating multiple diseases. Although they have great therapeutic effects, they unavoidably produce many side effects by long-term use. GCs-induced osteoporosis is a grave side effect and have become the main reason behind secondary osteoporosis in adults [20]. All the available osteoporosis pharmacological treatments carry a huge burden of multiple side effects and high cost [7].

In view of these facts, this study aimed to evaluate the bone healing ability of MO on GCs induced jawbone osteoporosis, and since animal models are vital for the testing of new treatments, the rat animal model was chosen for this study in order to easily develop a quick osteoporotic model [21].

In this study, osteoporosis was induced by a daily intraperitoneal injection of $200 \mu \mathrm{g} /$ $100 \mathrm{~g}$ dexamethasone for 30 days [18]. GCsinduced osteoporosis is identified by reduced bone formation, with an additional initial transient rise in bone resorption. The initial remodeling rate increase is escorted by decreased bone formation at the individual bone multicellular unit (BMU) level. The combination of the elevated bone turnover and the undesirable remodeling balance 

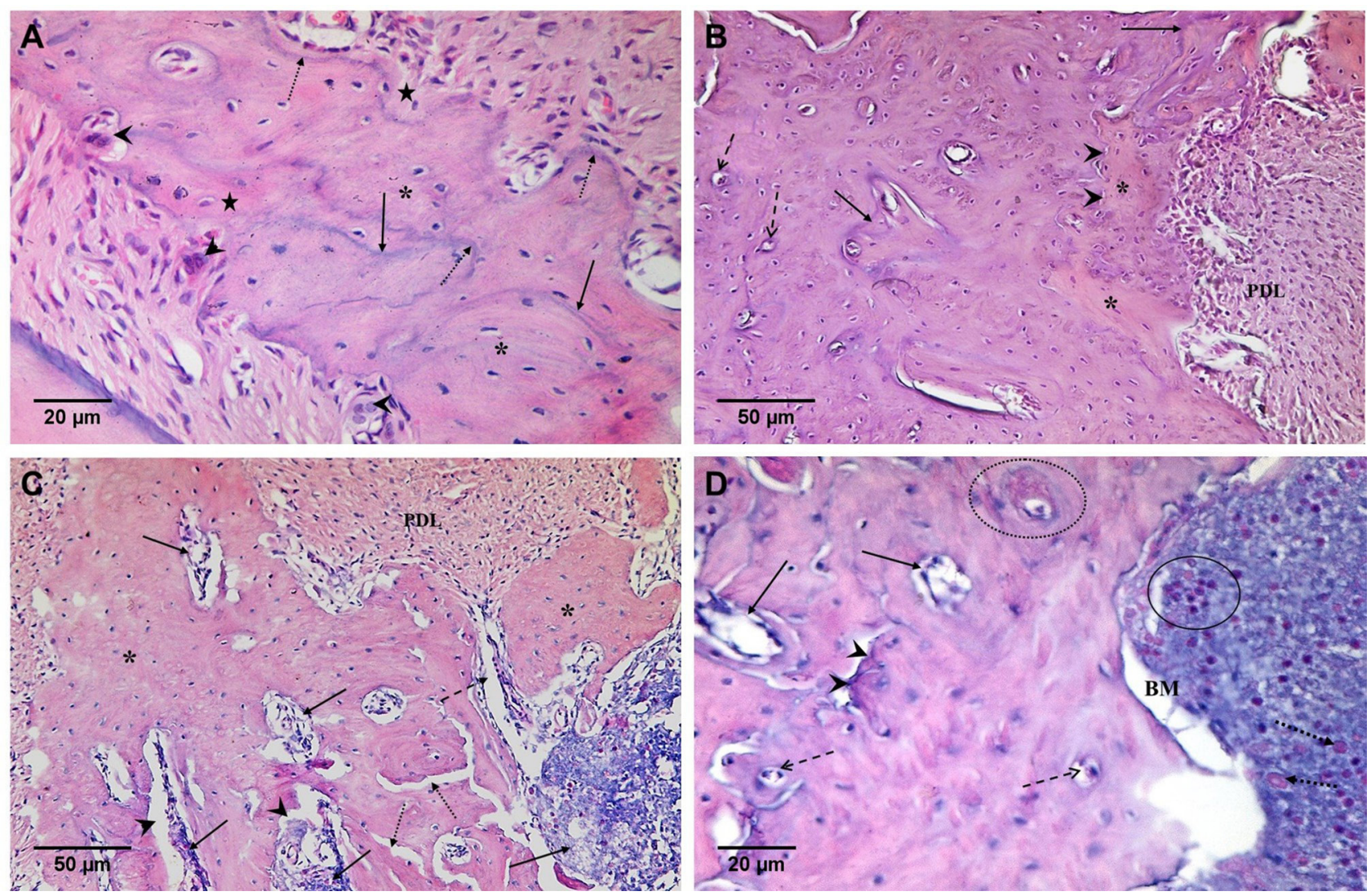

Figure 2 - A photomicrograph of the MO treated group showing (A) osteoclasts (arrow heads), bone resting lines (arrows), bone reversal lines (dotted arrows), osteoid formation (stars) and normal osteocytes in their lacunae (asterisks) (H\&E, original Mag. X400, scale bar=20 m); (B) bone vascular channels (dashed arrows), resting lines (arrows), reversal lines (arrow heads), newly formed bone matrix (asterisks) and normal periodontal ligaments (PDL) (H\&E, original Mag. X200, scale bar=50 $\mu \mathrm{m}$ ); (C) normal periodontal ligaments (PDL) connected to a nutrient canal (dashed arrow), bone marrow cavities with noticeably increased cellularity (arrows), with few areas with diminished osteoblastic lining (arrow heads), normal areas of bone trabeculae with normal osteocytes in their lacunae (asterisks) and fewer bone clefts (dotted arrows) (H\&E, original Mag. X200, scale bar=50 $\mu \mathrm{m}$ ); (D) a high magnification of a large cellular bone marrow cavity (BM) with multiple granulocytes (circle), megakaryocytes (dotted arrows), smaller bone marrow cavities with normal osteoblastic lining (arrows), reversal lines (arrow heads), vascular spaces (dashed arrows) and a secondary osteon (dotted circle) (H\&E, original Mag. X400, scale bar=20 $\mu \mathrm{m}$ )

causes a speedy bone loss. Afterwards, the declined bone formation, both at the tissue and BMU level, dominates causing a low turnover state [22].

In the present work, osteoporosis was examined in the mandibular jaw bone of an adult rat. It was proved that the mandible presents a considerably delayed and less intense response concerning the BMD loss compared to the femur bone in an osteoporotic rat model. It was also stated that the interradicular septum of the first molar was the commonly affected region, revealing the microarchitectural changes. That is why clinicians should be mindful that patients presenting with osteoporotic changes in the mandible are predicted to display severely advanced BMD reduction in other bone areas [23].

In the current study, bone weakening and deterioration were clearly noticed in the osteoporotic group through the decline of BMD. Similar results were shown by Govindarajan et al where the BMD was significantly lower in the ovarictomised (OVX) rats compared to the control ones [24].

In the present work, the RANKL gene expression was significantly elevated in the osteoporotic group, while the OPG gene expression was significantly decreased. Similarly Mo et al observed down-regulated OPG expression and up-regulated RANKL expression aroused by dexamethasone compared to healthy rats [25].

The histopathological findings of the osteoporotic group showed obvious bone deterioration. This comes in agreement with Mustafa et al where (OVX) osteoporotic rats revealed noticeable osteoporotic alterations in bone trabecular architecture [26]. In the current study, marrow cavities were filled with inflammatory cells. This is in agreement with Rauner et al who stated that cells of the immune system, such as T cells, B cells, macrophages or 
dendritic cells, become activated and produce inflammatory cytokines, which are crucial mediators in osteoimmunology and many of these cytokines cause osteoclasts stimulation [27]. Activated $\mathrm{T}$ cells act as major stimulators of osteoclastogenesis by increasing the boneresorbing cytokines production, especially TNF- $\alpha$ and RANKL. Hence, activated T cells are proposed to have a chief role in osteoporosis [28].

Overall, the activation of osteoclasts via these cytokines leads to exaggerated systemic and localized bone loss. Therefore, the excessive production of the bone-resorbing cytokines significantly explains the incidence of osteoporosis in conjunction with chronic inflammatory reactions. Remarkably, these cytokines are also of pathogenic importance in 'primary' forms of osteoporosis, like the age-related and postmenopausal osteoporosis [29].

The histomorphometric analysis in this study confirmed the histopathological architectural changes in the osteoporotic group, where the bone area percent values showed a great decline after the sacrifice. Kozai et al study went accordingly, where the steroid treatment significantly lowered the cortical thickness and bone volume of the rats' mandible compared to healthy animals [30].

In this study, the osteoporotic rats were given their regular rat chow and a daily oral dose of $200 \mathrm{mg} / \mathrm{kg}$ body weight of MO extract for 30 days [17]. Concerning the BMD, there was a significant elevation in BMD in MO treated group compared to the osteoporotic group. Moreover, the BMD in MO treated group was nearly similar to that of healthy rats as reported by Ezzat et al and Haggag et al [18,31]. Habib and Al-Moalem had similar results where BMD significantly increased in a glucocorticoid model of osteoporotic rats fed on dried moringa leaves. This could be attributed to the minerals found in $\mathrm{MO}$, which possess both a curative and preventive role against osteoporsis [32].

The RT-PCR analysis for the RANKL gene expression showed a significant decrease, while the OPG gene expression showed a remarkable increase in the MO treated group compared to osteoporotic group. In addition, gene expression levels of RANKL and OPG in MO treated group were close to those of healthy rats as stated by Meijie et al and Ma et al $[33,34]$. Adhikary et al had supporting results where dietary flavonoid kaempferol inhibited glucocorticoid induced bone loss. The oral uptake of kaempferol enhanced bone strength, BMD and bone formationrelated genes like OPG and decreased the bone resorption-related gene RANKL in kaempferol treated group [35]. These findings went in accordance with our results as the MO leaves extract were proved to possess an effective kaempferol content. The main flavonoids found in MO leaves ethanolic extract are the kaempferol and quercetin. Kaempferol is not only a powerful antioxidant and promotor of cancer cell apoptosis but it also prevents DNA damage [36].

The histopathological findings of the MO treated group revealed a noticeable improvement in bone microarchitecture resembling normal histology of mandibular alveolar bone in rats as described by Ezzat et al, Montaser et al and Sherif et al $[18,37,38]$. This comes in accordance with Patel et al who studied the MO leaf extract treatment at $200 \mathrm{mg} / \mathrm{kg}$ bodyweight on (OVX) rats for 30 days. They proved that bone formation process was increased by enhancement of the osteoblastic activity, which led to the improvement of ALP activity in MO treated groups. MO accelerated mineralization of the organic matrix, thus speeding up the bone healing [17].

Moreover, the bone marrow cavities showed an increased cellularity. This makes the MO leaves a significant source of regular cell reinforcements. This increased cellularity also indicated a regenerative response in the bone marrow [39]. In addition, some megakaryocytes were observed in the bone marrow. They are rare cells found in the bone marrow, responsible for the daily production of platelets into the bloodstream. They also act as regulators of bone marrow homeostasis [40].

Concerning the histomorphometric analysis, the bone area percent values increased in the MO treated group and approached the normal values in healthy rats as reported by Ezzat et al and Montaser et al $[18,37]$. Ei Behairy et al also had supporting results where the histomorphomeric analysis showed the highest mean value of bone area percent in the MO leaf powder aqueous extract injected at extraction site in dogs [41].

These osteoinductive properties of MO leaf extract may be attributed to its flavonoids content which stimulate the osteoblast proliferation and differentiation. Furthermore, tannins contained in MO leaf extract could also inhibit osteoclasts differentiation. Moreover, the MO phytoestrogens 
have a positive effect on the bone with stimulatory effects on osteoblast activity through estrogenmediated action [15].

\section{CONCLUSION}

Although MO is a cheap and easy to get plant, yet it was proved in the current study to have a powerful anti-osteoporotic effect, remarkable bone healing regenerative potential and a great safety profile, thus it could be used in treatment of osteoporosis through its oral intake.

\section{Conflict of Interest}

The authors have no proprietary, financial, or other personal interest of any nature or kind in any product, service, and/or company that is presented in this article.

\section{Funding}

This research did not receive any specific grant from funding agencies in the public, commercial, or not-for-profit sectors.

\section{Regulatory statement}

This study was conducted in accordance with all the guidelines and policies of the Institutional Animal Care and Use Committee (IACUC), Cairo University. The approval code for this study is: (CU-III-F-73-17).

\section{References}

1. Sáez-López P, Etxebarria-Foronda I, Mesa Lampre MP, Alonso García N, Sánchez Hernández N. Efficacy, cost, and aspects to take into account in the treatment of osteoporosis in the elderly. Rev Esp Geriatr Gerontol. 2019;54(3):156-67. http:// dx.doi.org/10.1016/j.regg.2018.11.007. PMid:30606499.

2. Ebrahimi Tavani M. Promoting People's Awareness and Health Literacy about Osteoporosis through 'the World Osteoporosis Day. International Journal of Musculoskeletal Pain Prevention. 2018 [cited 2021 Feb 10];3(3):91-5. http://ijmpp.modares.ac.ir/ article-32-29913-en.html

3. Reddy MS. Osteoporosis and periodontitis: discussion, conclusions, and recommendations. Ann Periodontol. 2001;6(1):214-7. http://dx.doi.org/10.1902/annals.2001.6.1.214. PMid:11887468.

4. Scheidt-Nave C, Bismar H, Leidig-Bruckner G, Woitge H, Seibel MJ, Ziegler R, et al. Serum interleukin 6 is a major predictor of bone loss in women specific to the first decade past menopause. J Clin Endocrinol Metab. 2001;86(5):2032-42. http://dx.doi. org/10.1210/jcem.86.5.7445. PMid:11344203.
5. Weinstein RS. Clinical practice. Glucocorticoid-induced bone disease. N Engl J Med. 2011;365(1):62-70. http://dx.doi. org/10.1056/NEJMcp1012926. PMid:21732837.

6. Swanson C, Lorentzon M, Conaway HH, Lerner UH. Glucocorticoid regulation of osteoclast differentiation and expression of receptor activator of nuclear factor- $\mathrm{KB}(\mathrm{NF}-\mathrm{\kappa B})$ ligand, osteoprotegerin, and receptor activator of $\mathrm{NF}-\mathrm{\kappa B}$ in mouse calvarial bones. Endocrinology. 2006;147(7):3613-22. http:// dx.doi.org/10.1210/en.2005-0717. PMid:16614077.

7. Skjødt MK, Frost M, Abrahamsen B. Side effects of drugs for osteoporosis and metastatic bone disease. Br J Clin Pharmacol. 2019;85(6):1063-71. http://dx.doi.org/10.1111/bcp.13759. PMid:30192026.

8. Abdull Razis AF, Ibrahim MD, Kntayya SB. Health benefits of Moringa oleifera. Asian Pac J Cancer Prev. 2014;15(20):85716. http://dx.doi.org/10.7314/APJCP.2014.15.20.8571. PMid:25374169.

9. Raja RR, Sreenivasulu M, Vaishnavi S, Navyasri DM, Samatha G, Geethalakshmi S. Moringa oleifera-An overview. RA J Appl Res. 2016;2(9):620-4. http://dx.doi.org/10.18535/rajar/v2i9.05.

10. Price CT, Langford JR, Liporace FA. Essential nutrients for bone health and a review of their availability in the average North American diet. Open Orthop J. 2012;6(1):143-9. http://dx.doi. org/10.2174/1874325001206010143. PMid:22523525

11. Kresnoadi U, Rahmania PN, Caesar HU, Djulaeha E, Agustono $B$, Ari MD. The role of the combination of Moringa oleifera leaf extract and demineralized freeze-dried bovine bone xenograft (xenograft) as tooth extraction socket preservation materials on osteocalcin and transforming growth factor-beta 1 expressions in alveolar bone of Cavia cobaya. J Indian Prosthodont Soc. 2019:19(2):120-5. http://dx.doi.org/10.4103/jips.jips_251_18. PMid:31040545.

12. Mbikay M. Therapeutic potential of Moringa oleifera leaves in chronic hyperglycemia and dyslipidemia: a review. Front Pharmacol. 2012;3:24. http://dx.doi.org/10.3389/ fphar.2012.00024. PMid:22403543.

13. Vali B, Rao LG, El-Sohemy A. Epigallocatechin-3-gallate increases the formation of mineralized bone nodules by human osteoblastlike cells. J Nutr Biochem. 2007;18(5):341-7. http://dx.doi. org/10.1016/j.jnutbio.2006.06.005. PMid:16963251.

14. Guo AJ, Choi RC, Zheng KY, Chen VP, Dong TT, Wang ZT, et al. Kaempferol as a flavonoid induces osteoblastic differentiation via estrogen receptor signaling. Chin Med. 2012;7:10. http:// dx.doi.org/10.1186/1749-8546-7-10. PMid:22546174.

15. Burali SC, Patil SL, Mandal M. The beneficial effect of ethanolic extract of moringa oleifera on osteoporosis. International Journal of Pharmaceutical Applications. 2010;1(1):50-8.

16. Khalil WKB, Ghaly IS, Diab KAE. Antitumor activity of Moringa Oleifera leaf extract against Ehrlich solid tumor. Int J Pharm. 2014 [cited 2021 Feb 10];4(3):68-82. Available from: http:// www.pharmascholars.com

17. Patel C, Ayaz RM, Parikh P. Studies on the Osteoprotective and Antidiabetic Activities of Moringa Oleifera Plant Extract. IOSR J Pharm. 2015 [cited 2021 Feb 10];5(5):19-22. Available from: www.iosrphr.org

18. Ezzat BA, Abbass MMS. The ability of $\mathrm{H} 1$ or $\mathrm{H} 2$ receptor antagonists or their combination in counteracting the glucocorticoid-induced alveolar bone loss in rats. J Oral Pathol Med. 2014;43(2):148-56. http://dx.doi.org/10.1111/jop.12104. PMid:23845021.

19. Gao SG, Li KH, Xu M, Jiang W, Shen H, Luo W, et al. Bone turnover in passive smoking female rat: relationships to change in bone mineral density. BMC Musculoskelet Disord. 2011;12:131. http:// dx.doi.org/10.1186/1471-2474-12-131. PMid:21663694. 
20. Mazziotti G, Angeli A, Bilezikian JP, Canalis E, Giustina A. Glucocorticoid-induced osteoporosis: an update. Trends Endocrinol Metab. 2006;17(4):144-9. http://dx.doi.org/10.1016/j. tem.2006.03.009. PMid:16678739.

21. Gao X, Ma W, Dong H, Yong Z, Su R. Establishing a rapid animal model of osteoporosis with ovariectomy plus low calcium diet in rats. Int J Clin Exp Pathol. 2014;7(8):5123-8. PMid:25197386.

22. Carbonare LD, Arlot ME, Chavassieux PM, Roux JP, Portero NR, Meunier PJ. Comparison of trabecular bone microarchitecture and remodeling in glucocorticoid-induced and postmenopausal osteoporosis. J Bone Miner Res. 2001;16(1):97-103. http://dx.doi. org/10.1359/jbmr.2001.16.1.97. PMid:11149495.

23. Lee C, Lee JH, Han SS, Kim YH, Choi YJ, Jeon KJ, et al. Site-specific and time-course changes of postmenopausal osteoporosis in rat mandible: comparative study with femur Sci Rep. 2019;9(1):14155. http://dx.doi.org/10.1038/s41598019-50554-w. PMid:31578360

24. Govindarajan P, Khassawna T, Kampschulte M, Böcker W, Huerter $B$, Dürselen $L$, et al. Implications of combined ovariectomy and glucocorticoid (dexamethasone) treatment on mineral, microarchitectural, biomechanical and matrix properties of rat bone. Int J Exp Pathol. 2013 Dec;94(6):387-98. PMID: 23998329.

25. Mo H, Zhang N, Li H, Li F, Pu R. Beneficial effects of Cuscuta Chinensis extract on glucocorticoid-induced osteoporosis through modulation of RANKL/OPG signals. Braz J Med Biol Res. 2019:52(12):e8754. http://dx.doi.org/10.1590/1414431×20198754. PMid:31826180

26. Mustafa MS, Mahmoud OM, Hussein HH. histological and morphometric effects of $\mathrm{cdcl} 2$ and ginger on osteoporosis induced by bilateral ovariectomy in adult albino rats. Eur J Anat. 2013;17(2):102-14

27. Rauner M, Sipos W, Pietschmann P. Osteoimmunology. Int Arch Allergy Immunol. 2007;143(1):31-48. http://dx.doi org/10.1159/000098223. PMid:17191007.

28. D'Amelio P, Grimaldi A, Di Bella S, Brianza SZM, Cristofaro MA, Tamone C, et al. Estrogen deficiency increases osteoclastogenesis up-regulating $T$ cells activity: A key mechanism in osteoporosis. Bone. 2008;43(1):92-100. http:// dx.doi.org/10.1016/j.bone.2008.02.017. PMid:18407820.

29. Pietschmann P, Mechtcheriakova D, Meshcheryakova A, Föger-Samwald U, Ellinger I. Immunology of osteoporosis: a mini-review. Gerontology. 2016;62(2):128-37. http://dx.doi. org/10.1159/000431091. PMid:26088283.

30. Kozai Y, Kawamata R, Sakurai T, Kanno M, Kashima I. Influence of prednisolone-induced osteoporosis on bone mass and bone quality of the mandible in rats. Dentomaxillofacial Radiol. 2009 [cited 2021 Feb 10];38(1):34-41. Available from: http://dmfr. birjournals.org

31. Haggag T, Mahmoud EF. Histological study of reparative capacity of silver nanoparticles on age related changes of alveolar bone, cementum and periodontal ligaments in rats. Egypt Dent $J$. 2018;64(4):3511-21. http://dx.doi.org/10.21608/edj.2018.91763.

32. Habib MK, Al-Moalem MH. Effect of Moringa leaves and seeds on osteoporosis in rats. J Food and Dairy Sci. 2018;2018(0):129-35. http://dx.doi.org/10.21608/jfds.2018.77771.

33. Liu M, Li YBAJDL, Pan J, Liu H, Wang S, Ju D, et al. Effect of esculetin on bone metabolism in ovariectomized rats. J Tradit Chin Med. 2018;38(6):896-903. http://dx.doi.org/10.1016/ S0254-6272(18)30989-0. PMid:32186137.

34. Ma Z, Li S, Sun Y. Effect of enhanced masticatory force on OPG, RANKL and MGF in alveolar bone of ovariectomized rats. J Appl Oral Sci. 2020;28:e20190409. http://dx.doi.org/10.1590/1678 7757-2019-0409. PMid:32267378

35. Adhikary S, Choudhary D, Ahmad N, Karvande A, Kumar A, Banala $V T$, et al. Dietary flavonoid kaempferol inhibits glucocorticoidinduced bone loss by promoting osteoblast survival. Nutrition. 2018;53:64-76. http://dx.doi.org/10.1016/j.nut.2017.12.003. PMid:29655780

36. Lin $M$, Zhang J, Chen X. Bioactive flavonoids in Moringa oleifera and their health-promoting properties. J Funct Foods. 2018;47:469-79. http://dx.doi.org/10.1016/j.jff.2018.06.011.

37. Montaser MM, Soliman S, Khalil NM, Eladawy M. Effect of Raloxifene in the prevention of osteoporosis of alveolar bone induced by high fat diet in rats. Alex Dent J. 2019;44(2):33-8. http://dx.doi.org/10.21608/adjalexu.2019.57360

38. Sherif H, El Masry NA, Kawana KY, Khalil NM. Effect of Bisphosphonates on the alveolar bone of rats with glucocorticoids induced osteoporosis. Alex Dent J. 2019:44(3):65-70 http:// dx.doi.org/10.21608/adjalexu.2019.63560

39. Morton D, Reed L, Huang W, Marcek JM, Austin-Lafrance $\mathrm{R}$, Northcott CA, et al. Toxicity of hydroxyurea in rats and dogs. Toxicol Pathol. 2015;43(4):498-512. http://dx.doi. org/10.1177/0192623314559103. PMid:25391310

40. Malara A, Abbonante V, Di Buduo CA, Tozzi L, Currao M, Balduini $A$. The secret life of a megakaryocyte: emerging roles in bone marrow homeostasis control. Cell Mol Life Sci. 2015;72(8):1517-36. http://dx.doi.org/10.1007/s00018-0141813-y. PMid:25572292.

41. El behairy RAA, Ramadan NA, El Rouby D, Ahmed IH. Improvements of alveolar bone healing using Moringa oleifera leaf powder and extract biomimetic composite: an experimental study in dogs. EDJ. 2019;65(3):2219-32. http://dx.doi. org/10.21608/EDJ.2019.72248.

\section{Nermeen AbuBakr \\ (Corresponding address)}

Cairo University, Oral Biology Department, Faculty of Dentistry, Cairo, Egypt.

Email: nermeen.abubakr@dentistry.cu.edu.eg 